\title{
Multivariate Linear Regression Model for the Impact of China Family Business Succession on R\&D Intensity
}

\author{
Jun Kong ${ }^{1,2, *}$, Sidi Wang ${ }^{1}$ and Fan Jiang ${ }^{3}$ \\ ${ }^{1}$ School of Economics and Management, Northwest University, China \\ ${ }^{2}$ Westchina Economic and Development Center, Xi'an, China \\ ${ }^{3}$ Department of Economics, Texas Tech University, US \\ *Corresponding author
}

Keywords: Family firm, R\&D, Succession, Institution environment

\begin{abstract}
This study investigates the impact of China family business succession on R\&D intensity by multivariate linear regression model and CSMAR data. The regression result shows that succession experience decreases Chinese family firms’ R\&D intensity. Moreover, succession timing has a significant positive effect. The higher R\&D intensity Chinese family firms do. Post-succession positions of successor are also positively associated with R\&D intensity. No significant impacts are located for incumbent-successor relationship and succession order. At last, all control variables among different models show consistent effects on R\&D intensity, which suggest robustness of our analyses.
\end{abstract}

\section{Introduction}

This paper uses China Stock Market \& Accounting Research (CSMAR) database data which covers family firms listed in Small and Medium-sized Enterprise (SME board) and Growth Enterprise Market (GEM board) from 2004 to 2012 to answer the research question: is there any significant difference in R\&D intensity between succession and non-succession Chinese family firms in same industry and province? We find significant difference between succession group and non-succession group. More specific, succession experience decreases Chinese family firms' R\&D intensity. Post-succession positions of successor are also positively associated with R\&D intensity. No significant impacts are located for incumbent-successor relationship and succession order.

\section{Hypothesis Development}

Succession is a process that new owners from family enter the business, add new resources and have the consequences and outcomes like innovation. The founder considers the family firm succession as a chance to release the resource and the successor believes succession as a chance to invest resource. The outcome like innovation depends on the extent of both founder and successor's resources input[1]. Assuming family business succession can influence the firm's R\&D. Dividing family firm succession into several succession variables, for example, age and education for founder and successor, succession timing, founder-successor relationship, succession order, successor's post-succession position, affect R\&D intensity, helps us build a better understanding of their impacts on innovation. [2] find that younger CEO invests more on R\&D. The literature has identified the linkage between high education level and high cognitive ability, information processing ability and high risk taking to innovation[3]. [4] suggest that well educated top managers have high propensity to deviate from current status and put strategy changes into application. We believe higher education level will lead to higher R\&D intensity. We propose hypotheses to be tested: The older the founder is, the higher R\&D intensity in family firm; the more education founder receives, the higher R\&D intensity in family firm; the older the successor is, the higher R\&D intensity in family firm; the more education successor receives, the higher R\&D intensity in family firm. 


\section{Research Design}

Sample data is from China Stock Market \& Accounting Research (CSMAR) Database. The data covers family firms listed in Small and Medium-sized Enterprise (SME board) and Growth Enterprise Market (GEM board) from 2004 to 2012. R\&D intensity is dependent variable in most of our regression models. It's measured as the ratio of R\&D expenditures to the total assets following the standard analysis. Multivariate Linear Regression Model is used to analyse the Impact of China Family Business Succession on R\&D Intensity.

The independent variable is succession dummy only, which is coded 1 if succession takes place in family firm and coded 0 if not. The succession dummy variable is used to explore if the succession can actually influence the $R \& D$ intensity. Six control variables are considered in this paper. Firm size is controlled and measured as the logarithm of the number of employees. Debt is controlled and measured as the ratio of total debt to total assets. Age is measured as the logarithm of the years that family firm had been in existence. Profitability is measured as return on assets. Growth is measured as percentage annual growth of sales. Free cash flow is measured as cash from operating activities as a percentage of current liabilities.

\section{Empirical Analysis and Results}

Since the t-test results suggest significant difference between succession and control group in Table 1 , a natural extension is to estimate impact of succession on R\&D intensity. Then explore the different succession variables' impacts. To isolate the impact of family business succession on R\&D intensity, the regressions are conducted in a stepwise fashion. As illustrated in Table 2, model 1 examines the succession effects on family firm and indicates a significant negative impact $(-0.005)$ on $R \& D$ intensity $(\mathrm{P}<0.01)$. In addition, a larger family firm is associated with a decrease in $R \& D$ intensity $(\mathrm{P}<0.05)$. High leverage family firms also tend to lower their $R \& D$ intensity $(P<0.01)$ since they want to save some $R \& D$ funding to service the debt. High growth family firms exhibit a decrease in $R \& D$ intensity as well $(\mathrm{P}<0.01)$. All the Chinese family firms in our analysis are small and medium firms and those firms prefer expansion rather than innovation if they can actually have a good performance on sales growth. Become bigger and build more connections with multilevel of governments help Chinese family firms live longer. Other control variables like age, profitability and cash flow ratio are not significant in model 1. Model 2 in Table 2 represents the regression without succession. Control variables like size, debt and growth are significant and almost have same impacts compared with model 1 . Wald test also suggests the changes in adjusted $\mathrm{R}$ square between model 1 and model 2 is significant. From Table 2, we find out a robust support to negative impact of succession on R\&D intensity.

The succession variables are categorized into two parts: (a) age and education; (b) succession arrangements. For age and education, I focus on succession participants' characteristics like incumbent's age and education, successor's age and education. The age gap and education gap are also added to gain deeper results. For succession arrangements, I emphasize the factors about succession process like succession timing, incumbent-successor relationship, succession order and successor's post-succession positions.

Table 3 represents the regression results of impact of age and education on R\&D intensity. Six independent variables, incumbent's age and education, successor's age and education, the age gap and education gap, enter analysis stepwise. The results of model 2,3,4,5 and 7 in Table 3 show that incumbent's age and education, successor's age and education and education gap are not significantly associated with R\&D intensity. However, model 3 suggests the age gap has a positive impact on R\&D intensity. These findings indicate that succession participants' characteristics are not a big concern in Chinese family firms' $R \& D$ decision. The only exception show up if the incumbent is much older than successor. It's consistent with Chinese culture that parents usually spoil the youngest family members. They are willing to give more support if there's a larger age gap between themselves and their kids. For family business founders in China, if they have a larger age 
gap with their successors, they have higher propensity to invest more in R\&D so that their successors can take over a better family business in the future.

Table 4 shows the regression results of impact of succession variables on R\&D intensity. Model 2 includes succession timing and controls and reports a significant positive effect $(\mathrm{P}<0.01)$. This result lends support to $\mathrm{H} 6$ and suggests the later succession takes place, the higher R\&D intensity Chinese family firms do. Founders want to pass a better family business on to their successors if they keep leadership on their hands, which lead to higher investment in R\&D. From model 5, I find post-succession positions of successor are also positively associated with $R \& D$ intensity $(P<0.1)$, implying Chinese family's control rights over family firm is an important determinant of their willingness to invest in R\&D. Higher positions that family successor take after succession reflect greater control rights family successor hold. The new leader wants to avoid mistakes and makes everything on his or her track, so successor is going to be more managerial risk averse. Therefore, the long term oriented R\&D intensity usually gets discouraged by family firms. The impacts of incumbent-successor relationship and succession order on R\&D intensity are discussed in model 3 and model 4. For incumbent-successor relationship, may be the male dominant Chinese society is a possible reason. Under Chinese and other Asian cultures, sons have priority to inherit property and leadership. Therefore, son actually is exogenous among incumbent-successor relationships so that I find insignificant result.

Table 1. T-test Result for R\&D Intensity Difference between Control and Succession Group

\begin{tabular}{llllllc}
\hline Group & Obs & R\&D Mean & SE & SD & \multicolumn{2}{l}{ 95\% Confident Intervals } \\
\hline Control & 227 & 0.0374 & 0.0014 & 0.0214 & 0.0346 & 0.0402 \\
Succession & 124 & 0.0329 & 0.0015 & 0.0172 & 0.0298 & 0.0359 \\
\hline Combined & 351 & 0.0358 & 0.0011 & & 0.0337 & 0.0379 \\
Difference & & 0.0045 & 0.0022 & & 0.0001 & 0.0089 \\
\hline T Statistics & 2.0093 & & & & P-value & $0.0226^{* *}$ \\
\hline
\end{tabular}

Note: $*, * *, * * *$ represent significant results associated with $\mathrm{P}<0.1, \mathrm{P}<0.05$, and $\mathrm{P}<0.01$. Difference $=\mathrm{R} \& \mathrm{D}$ mean (control group) $-\mathrm{R} \& D$ mean (succession group). Ho: Difference $=0$; Ha: Difference $>0$.

Table 2. The Impact of Family Business Succession on R\&D Intensity

\begin{tabular}{cccc}
\hline & Variables & Model 1 & Model 2 \\
\hline Independent & Succession & $-0.005^{* * *}$ & {$[-2.69]$} \\
Controls & Size & $-0.003^{* *}$ & $-0.003^{* *}$ \\
& Age & {$[-2.06]$} & {$[-1.98]$} \\
& & -0.002 & -0.003 \\
& Profitability & {$[-0.74]$} & {$[-0.88]$} \\
& Debt & 0.009 & 0.013 \\
& & {$[0.42]$} & {$[0.59]$} \\
& Growth & $-0.023^{* * *}$ & $-0.021^{* * *}$ \\
& & {$[-3.36]$} & $-0.007 * * *$ \\
& Cash Flow Ratio & $-0.008^{* * *}$ & {$[-2.63]$} \\
& {$[-2.78]$} & 0.002 \\
& Constant & 0.001 & {$[0.37]$} \\
& & {$[0.34]$} & 0.024 \\
& N & 0.029 & {$[1.37]$} \\
& R Square & {$[1.65]$} & 351 \\
& Adjusted R Square & 0.255 & 0.239
\end{tabular}


Table 3. The Impact of Age and Education on R\&D Intensity

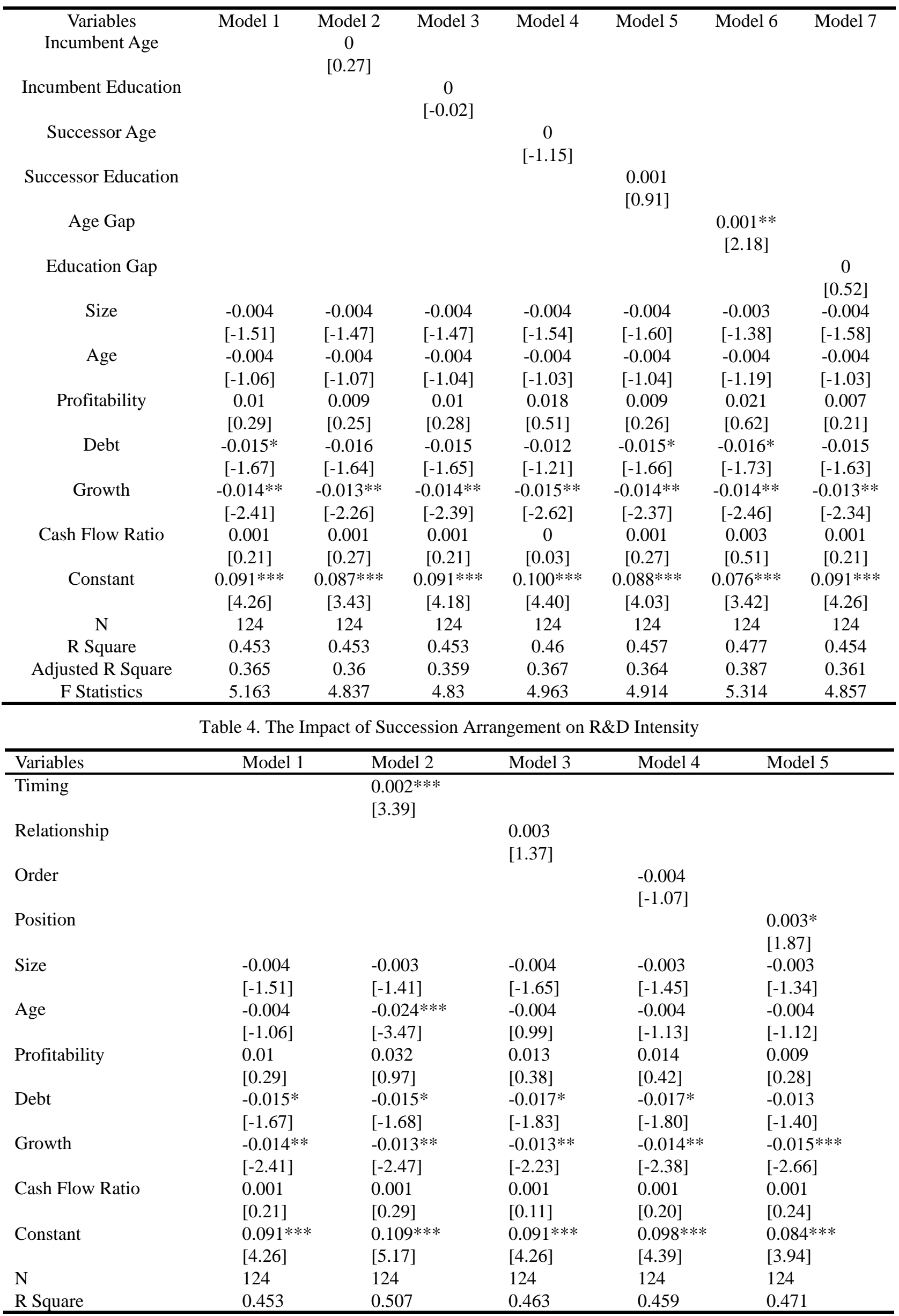




\begin{tabular}{llllll}
\hline Adjusted R Square & 0.365 & 0.422 & 0.37 & 0.366 & 0.38 \\
F Statistics & 5.163 & 5.995 & 5.02 & 4.947 & 5.187 \\
\hline
\end{tabular}

\section{Conclusion}

This paper uses Multivariate Linear Regression Model and CSMAR data from 2004 to 2012 to estimate the impact of family business succession on R\&D intensity. We find that succession experience decreases Chinese family firms’ R\&D intensity. Moreover, succession timing has a significant positive effect. The higher R\&D intensity Chinese family firms do. Post-succession positions of successor are also positively associated with R\&D intensity. No significant impacts are located for incumbent-successor relationship and succession order. At last, all control variables among different models show consistent effects on R\&D intensity, which suggest robustness of our analyses. It is concluded that if founder keeps the leadership longer and appoint successor a lower level position after succession, family firm tends invest more in R\&D.

\section{References}

[1] Nordqvist $M$, Wennberg $K$, Hellerstedt $K$. An entrepreneurial process perspective on succession in family firms[J]. Small Business Economics, 2013, 40(4): 1087-1122.

[2] Barker III V L, Mueller G C. CEO characteristics and firm R\&D spending[J]. Management Science, 2002, 48(6): 782-801.

[3] Datta D K, Guthrie J P. Executive succession: Organizational antecedents of CEO characteristics[J]. Strategic Management Journal, 1994, 15(7): 569-577.

[4] Wiersema M F, Bantel K A. Top management team demography and corporate strategic change[J]. Academy of Management journal, 1992, 35(1): 91-121. 